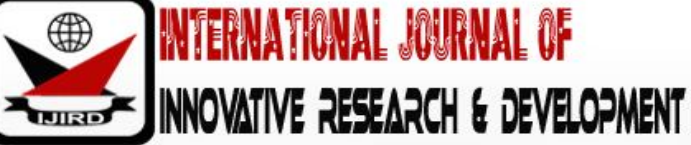

ISSN 2278 - 0211 (Online)

\section{Exchange Rate Devaluation and Balance of Trade in Nigeria: An Error Correction Model Approach}

Dr. Akinwale, S.0.
Senior Lecturer, Department of Banking and Finance, Adekunle Ajasin University, Akungba, Nigeria
Solawon, Modupeoluwa Deborah
Assistant Lecturer, Department of Banking and Finance, Adekunle Ajasin University, Akungba, Nigeria
Adekunle E. Oludayo
Researcher, Department of Banking and Finance, Adekunle Ajasin University, Akungba, Nigeria
Obagunwa, T. Oluwabusayo
Researcher, Department of Banking and Finance, Adekunle Ajasin University, Akungba, Nigeria

\section{Abstract:}

An effective and stable exchange rate forms the major policy trust of monetary authority because it determines the external and internal balance of a nation in terms of trade position and stability of other macroeconomic variables. This study assessed the effect of exchange rate on balance of trade in Nigeria employing data that spanned from 1986 to2016 from Central Bank of Nigeria Statistical Bulletin. The study employed Augmented Dickey Fuller Test, Johansen Co-integration Test and Error Correction Model to examined the effect of balance of trade, exchange rate, export, import and interest rate. Correlation matrix was adopted to examine the direction of relationships among the macroeconomic variables. The stationary test result indicated that, all the variables were stationary at first difference. Also, the Johansen Co-integration test result indicated that there is a long run equilibrium relationship among the macroeconomic variables. The result of the Error Correction Model regression indicated that both export and import had significant effect on balance of trade while exchange rate and interest rate had insignificant effect on balance of trade. Based on findings of the study it was concluded that, exchange rate regime in Nigeria had insignificant effect on Nigeria trade balance which has continued to effect the country's international trade position negatively. It was recommended that, monetary authorities should design effective exchange rate regime so to ensure exchange rate stability which has the capacity to improve the trade position of the country. Government should ensure macroeconomic variables stability. Variables like interest rate, inflation rate and others should be closely monitored and controlled so as to provide stable environment that is capable of enhancing local investments.

Keywords: Balance of trade, exchange rate, export, import, interest rate

\section{Introduction}

Exchange rate constitutes an important macroeconomic indicator, because policies on exchange rate affect the investment decisions both locally and internationally. According to Genc and Artar (2014) the trade accomplishment of an economy can be determined by foreign exchange rate through reduction in trade deficit and maintenance of trade balance. Thus, a stable exchange rate regime could enhance the competitiveness of domestic industries through increase in price of foreign goods and services in relation to domestic counterpart (Kadil, 2004).

Umaru and Osame (2013) opined that literatures on exchange rate has continued to expand over time because exchange rate is important in determining the prices which connects domestic and world markets for goods and assets and also signals the trade competitiveness of a nation with respect to world countries. Thus, the effective management of exchange is one of the major concerns of policies makers and technocrats in the $21^{\text {st }}$ century. The macroeconomic policies framework of both developed and developing nations is build upon an effective exchange rate regime that can enhance medium and long term sustainable internal and external macroeconomic balances. As a result of this, countries are shifting away from the conventional fixed exchange rate regime to a more flexible and floating exchange rate regime creating room for more exchange rate uncertainty (Odili, 2015).

Exchange rate devaluation involves the authorized reduction in the value of local currency in relations to international currency thereby bossing exports of the country through increase in price of foreign goods and reduction in price of export hence leading to favorable trade balance (Khan, Ali \& Ali, 2016). It is widely believed that macroeconomic policy of devaluating exchange rate has expansionary effects on domestic production and incomes through increase country's exports and reduces imports due to changes in terms of trade and the effect of price elasticity of demand (Kang, 2016). Galebotswe and Andrias (2011) asserted that this is because exchange rate devaluation enhances exports through reduction in export price and reduces imports through increase in price of import thereby leading leaning to increase in 
foreign reserves. However, theoretically, an ambiguous relationship is predicted as exchange rate volatility can either stimulate or depress trade (Cote, 1994; Odili, 2014). From a policy point of view, evidence of exchange rate uncertainty adversely affect trade balance especially in developing countries due to lack of hedging instruments which may compel governments to intervene in foreign currency markets (Odili, 2015).

The Nigerian exchange rate and trade policies thrust in the recent years hover around integrating the economy into the global market system in order to enhanced competiveness and promotes economic growth. Umaru and Osame (2013) asserted that Nigeria's tariff and trade policies have been characterized by uncertainty and counter policies which led to the establishment of interbank foreign exchange market (IFEM), the autonomous foreign exchange market (AFEM), and the Dutch auction system (DAS) in order avoid overvaluation of the Naira exchange rate and boost non-oil export through which the naira depreciated consistently against major foreign currencies with the expectation of boosting export performance.

In 1986, exchange rate was liberalized through the adoption of Structural Adjusted Programme which led to movement towards a more market based exchange rate system in which exchange rate was determined by the forces of demand and supply for currency (Odili, 2015). This resulted in the liberalization of exchange rate and some other macroeconomic variables like interest rate in order to ensure both internal and external balances in the economy. However, despite the exchange rate reforms and regimes being adopted by successive governments in achieving both internal and external balance, the extent to which these policies have been effective in promoting intending macroeconomic goals remained unascertained and widely debated with the growth performance of Nigerian economy being sluggish in spite of the abundance resources abound in the country. Currently, the Nigerian economy is characterized by low manufacturing productivities, inflationary pressure, escalating debt burden, unemployment rate, income inequality, poverty, underutilization of resources, unfavorable trade balance and macroeconomic variables instability among others (Uniamikogbo \& Ewanehi, 1998; Ismaila, 2016). Thus, this paper examined the efficacy of exchange rate devaluation on balance of trade in Nigeria. The remaining part of this paper was divided into literatures review, methods adopted, presentation and interpretations of results with conclusion, implication and recommendations as the final part.

\section{Review of Related Literatures}

\subsection{Conceptual Issues}

Exchange rate is the price of one country's currency in relation to another country. Exchange rate is the price of the currency of one country expressed in terms of the currencies of other nations of the world. Thus, the effective management of exchange rate is a necessary prerequisite maintaining stable macroeconomic variables and growth (Oloyede, 2002; Fapetu \& Oloyede, 2014).

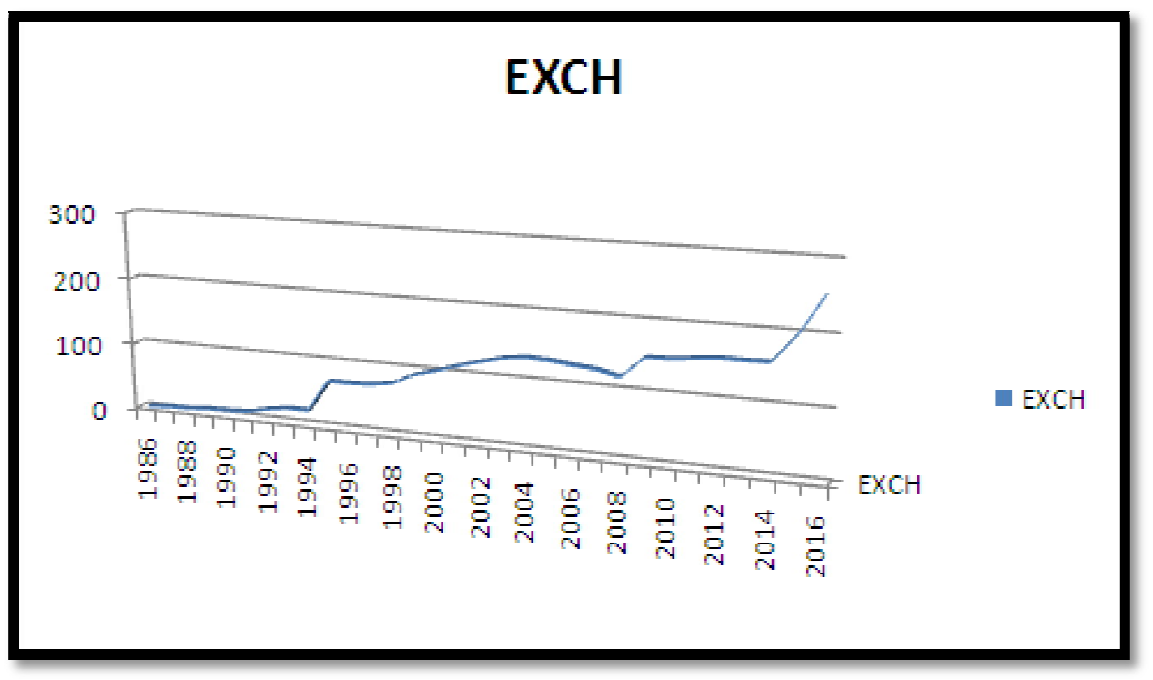

Figure 1: Exchange Rate in Nigeria Sources: CBN Bulletin, 2016

Figure 1 indicates the trends in exchange rate over the period of 1986 to 2016. The Nigerian exchange rate was low from 1986 to 1994 following the adoption of Structural Adjusted Programme in 1986. The exchange rate however continued to appreciate from 1996 and remained at stable rate through 2008 before shutting up through 2016. This is an indication of frequent change in exchange rate regime in Nigeria.

Exchange rate may be expressed as nominal exchange rate or real exchange rate (Okorontah \& Odoemena, 2016). An exchange rate system can also be fixed or flexible. A fixed exchange rate is a system in which exchange rate is manage by regulatory authorities while floating exchange rate is an exchange rate system which is determine by the interaction of demand and supply (Black 2003 cited in Okorontah \& Odoemena, 2016).

International trade is the exchange of goods and services among nations of the world. The need for international trade results from the fact that countries are interdependent which as a result of differences in endowment of resources among nations. Thus, nations need to generate enough revenue through sales of local goods and services in order to 
finance the purchase of goods and services which cannot be produced domestically from foreign countries (Adeleye, Adeteye and Adewunmi, 2015).

Imoughele and Ismaila (2015) asserted that exchange rate the flow of goods and services are affected by the movement of exchange rate thereby influencing balance of trade and balance of payments position. Therefore, effective exchange rate management plays critical role in maintaining both internal and external balance. According to Omofowam (2014) argued that the exchange rate plays an important role in the economy because it is the most important index in pricing foreign goods and services. With this regard Afolabi, Danladi and Azeez (2017) opined that international trade serves a linkage among nations through the flows commodities capital and productions factors.

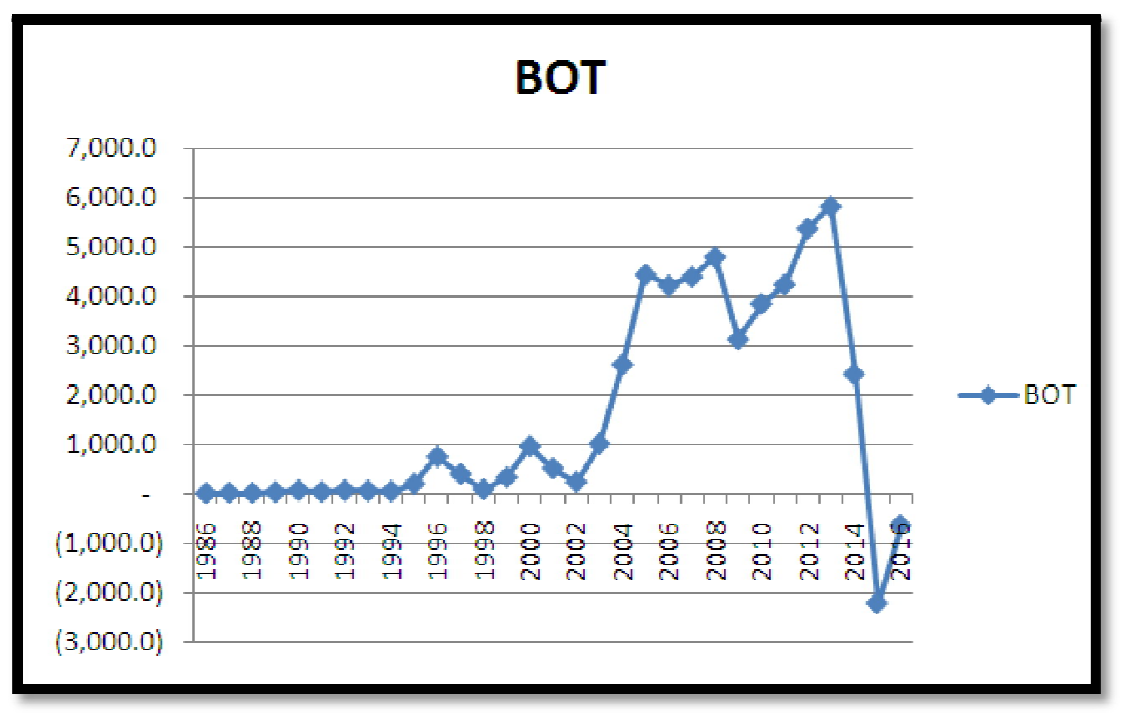

Figure 2: Trade Balance in Nigeria Source: CBN Bulletin, 2016

Figure 2 revealed the trends of the Nigerian Balance of Trade over the years. It was indicated that the balance of trade was low between 1986 and 2002. Hoverer, there was a significant rise in the balance of trade from the last quarter of 2004 before dropping in 2008. Furthermore, there was a slight rise in 2012 before witnessing a significant drop from the last quarter of 2012. The balance of trade was negative in 2014 through 2016 which resulted from recessionary pressure experienced by the country in the first quarter of 2015.

\subsection{Empirical Review}

Kandil (2004) examined the effects of exchange rate fluctuations on real output growth and price inflation using twenty-two developing countries. It was found that exchange rate depreciation had negative effect real output growth but had positive effect on inflation. Galebots we and Andri as (2010) examined the contractionary devaluation hypothesis in the context of a small open import-dependent economy. Using an error-correction model, the study found that currency devaluations are contractionary in the long run and expansionary in the short-run.

Ogbonna (2011) examined the empirical relationship between the real exchange rate and aggregate trade balance of Nigeria using regression model. The results of the analysis indicated there is no co integration for the trade balance model. Umoru and Oseme (2013) explored the J-curve effect based on Nigerian data by adopting the vector error correction methodology. The results of the study indicated a cyclical feedback between the trade balance and the real exchange rate depreciation of the Naira. Shehu (2013) used time series data obtained from the Central Bank of Nigeria statistical bulletin to examined the impact of foreign exchange rate volatility on the changes of SITC imports value in Nigeria under the three foreign exchange market regime. The study positive and highly negative significant relationship between exchange rate volatility and changes in SITC imports value under second-tier Foreign Exchange Market (SFEM) and Inter-Bank Foreign Exchange Market (IFEM) respectively.

Genc and Artar (2014) examined the effect of exchange rates on exports and imports of emerging countries from of 1985 to 2012 using from the World Bank data base. It was discovered that, there is co- integrated relationship between effective exchange rates and exports-imports of emerging countries in the long run. Omofowam (2014) investigated the impact of exchange rate on import and export of China for the period of 2005M1 to 2013M12 using descriptive statistics and Co-integration analysis which is the strategic method used in investigating this problem. The overall result movement in exchange rate will result in volume of trade movement.

Odili (2015) investigated the effect of exchange rate trends and volatility on Nigeria's imports from 1971 to 2011 by employed co-integration and Parsimonious ECM model using Schwarz criterion and Akaike information criterion as lag length selection criterion. The findings revealed that exchange rate trends had positive and significant effect on imports only in the long run and that exchange rate volatility depressed imports. Fatai and Akinbobola (2015) investigated the impact of Exchange Rate Pass-through (ERPT) to import prices, Inflation, and monetary policy in Nigeria using secondary from 1986 to 2012. Based on SVAR analysis the study found that ERPT in Nigeria during the period under review is moderate, significant and persistent in the case of import prices and low and short lived in the case of inflation. Khan et al. (2016) investigated the impact of devaluation on balance of trade and on the external debt, in case of Pakistan, over the 
period of 1980 to 2014 by employing ARDL (Autoregressive distributed lag model) econometric technique. The result of the analysis found there exist a relationship between exchange rate and balance of trade.

It could be seen from the liletaures reviewed above that the issues of exchange rate and trade balance have dominated academics writings and serve as concerns to policy makers. It is widely believed that the value of a country currency in relation to other country currency will have an effect on import and export thereby affecting trade position of such country. Study of this nature is very meager in Nigeria and the one available revealed different relationship between exchange and importation of goods and services thereby creating the gap of what actually is the relationship between exchange rate and balance of trade in Nigeria. This research work was undertaken to fill this gap so as to reveal the actual relationship between exchange rate and balance of trade and how it affect the country's trade position and economy at large. The study made use of data from CBN Bulletin and World Development Indicators. It is expected that findings from this study will be of immense use to policy makers given the current situation of exchange rate in the economy and will also contribute to the few works in the subject area.

\section{Methods}

The data for this study was quantitative in nature which was obtained from Central Bank of Nigeria Statistical Bulletin (2016). Expo factor research design was adopted to examine the relationship between the dependent variable (proxy as Balance of Trade) and the explanatory variables (proxy as Exchange Rate, Export, Import and Interest Rate). This design was consider suitable because the study made used of secondary data which were historical and non manipulative in nature.

\subsection{Measurement of the Variables}

- Balance of Trade (BOT): This is measured as the difference between export and import in Nigeria in monetary term.

- Exchange Rate: This is the rate at which a country's currency is exchange for foreign currencies. This study makes used of Naira/ Dollar Exchange Rate

- Export: This is the total monetary value of goods that is sold to other nations and it is measured in Naira.

- Import: This is the monetary value of goods bought from other countries.

\subsection{Model Specification}

In order to capture the exchange rate on balance of trade in Nigeria, a multiple regression model was be formulated. This is given as:

$\mathrm{BOT}=\mathrm{f}(\mathrm{EXR}, \mathrm{EXP}, \mathrm{IMP}, \mathrm{INTR})$

The linear equation of this model can be written as:

$\mathrm{BOT}_{\mathrm{t}}=\lambda_{0}+\lambda_{1} \mathrm{EXR}_{\mathrm{t}}+\lambda_{2} \mathrm{EXP}_{\mathrm{t}}+\lambda_{3} \mathrm{IMP}_{\mathrm{t}}+\lambda_{4} \mathrm{INTR}_{\mathrm{t}}+\mathrm{e}_{\mathrm{t}}$

Where:

BOT $=$ Balance of Trade

EXR $=$ Exchange Rate

EXP $=$ Export

$\mathrm{IMP}=$ Import

INT $=$ Interest Rate

$\mathrm{B}_{0}=$ Constant Term

$\lambda_{1}-\lambda_{4}=$ Parameters of the variables to be estimated

$\mathrm{e}=$ Stochastic Error Term

The Vector Error Correction Model describes the dynamic relationship among stationary macroeconomic variables through the evaluation of short run properties of a cointegrated time series data and also establishes the speed of adjustment across macro variables in the long run. The use of the Error Correction Model is appropriate when variables are stationary at first difference and co-integrated. However, when variables are co-integrated, it confirms the existence of long-run relationship.

$$
\begin{aligned}
& \mathrm{BOT}_{\mathrm{t}}=\beta_{0}+\sum_{i=0}^{n} \beta 1 \mathrm{i} \triangle \mathrm{BOT}_{\mathrm{ti}}+\sum_{\mathrm{i}=0}^{n} \beta 2 \mathrm{i} \triangle \mathrm{EXCH}_{\mathrm{t}-\mathrm{i}}+\sum_{i=0}^{n} \beta 3 \mathrm{i} \triangle \mathrm{EXP}_{\text {t- }-\mathrm{i}}+\sum_{i=0}^{n} \beta 4 \mathrm{i} \triangle \mathrm{IMP}_{\mathrm{t}-\mathrm{i}}+ \\
& \sum_{i=0}^{n} \beta 5 \mathrm{i} \triangle \mathrm{INT}_{\mathrm{t}-\mathrm{j}}+\lambda \mathrm{ECT}_{\mathrm{t}-1}+\mathrm{e}_{\mathrm{t}}
\end{aligned}
$$

\subsection{Evaluation Techniques}

In order to evaluate the effect of exchange rate on international trade in Nigeria, the study adopt Error Correction Model version of Ordinary Least Square in order capture the effect of as Exchange Rate, Export, Import and Interest Rate on Balance of Trade. The analysis commenced by testing the time series properties of data employed in the estimation equation for stationary using Augmented-Dick-Fuller (ADF) unit root test in order to avoid the problem of spurious regression. Also, Johansen Co-integration test was used to establish the long run relationship among the variables. An Error Correction Mechanism is employed to ascertain the speed of adjustment from the short run equilibrium to the long run equilibrium state and to establish the parameters of the coefficient among the variables. 


\section{Presentation and Interpretations of Results}

\subsection{Correlation Matrix}

\begin{tabular}{|c|c|c|c|c|c|}
\hline & BOT & EXCH & EXP & IMP & INTR \\
\hline BOT & 1.000000 & & & & \\
\hline EXCH & 0.424233 & 1.000000 & & & \\
\hline EXP & 0.759268 & 0.779730 & 1.000000 & & \\
\hline IMP & 0.483238 & 0.821028 & 0.936634 & 1.000000 & \\
\hline INTR & -0.280432 & -0.300075 & -0.421128 & -0.416350 & 1.000000 \\
\hline
\end{tabular}

Table 1: Correlation Matrix

Source: Authors' Computation, 2018

Table 1 showed the correlation matrix for the macroeconomic variables employed in this study. The table indicated that Exchange Rate, Export and Import were positively correlated with Balance of Trade. This implies that an increase in the Exchange Rate, Export and Import will result in increase in Balance of Trade. Finally, Interest Rate had negative effect on Balance of Trade indicating an increase in Interest Rate will result in Balance of Trade.

4.2. Stationary Test

\begin{tabular}{|c|c|c|c|c|c|}
\hline Variables & Test Statistic & $\begin{array}{c}\mathbf{5 \%} \text { Critical } \\
\text { Value }\end{array}$ & Prob. & Level & S/ NS \\
\hline BOT & $/ 5.374512 /$ & $/ 2.971853 /$ & 0.0001 & $1(1)$ & $\mathrm{S}$ \\
\hline EXCH & $/ 3.307283 /$ & $/ 2.967767 /$ & 0.0238 & $1(1)$ & $\mathrm{S}$ \\
\hline EXP & $/ 4.006117 /$ & $/ 2.967767 /$ & 0.0045 & $1(1)$ & $\mathrm{S}$ \\
\hline IMP & $/ 4.395640 /$ & $/ 2.967767 /$ & 0.0017 & $1(1)$ & $\mathrm{S}$ \\
\hline INTR & $/ 6.067046 /$ & $/ 2.967767 /$ & 0.0000 & $1(1)$ & $\mathrm{S}$ \\
\hline
\end{tabular}

Table 2: Analysis of Unit Root

Source: Authors' Computation, 2018

Table 3 presents the stationarity test of the variables. It was revealed that the macroeconomic variablesnamely; Balance of Trade, Exchange Rate, Export, Import and Interest Rate were free from unit root tangle at first difference i.e. 1(1). Since all the macroeconomic variables are stationary at first difference 1(1), then, the study employed the Johansen Co-integration Test and Error Correction Model.

\subsection{Co-Integration Test}

\begin{tabular}{|c|c|c|c|}
\hline Trace Statistic & 0.05 Critical Value & Hypothesized No of CE(S) & Prob $^{* *}$ \\
\hline 146.4911 & 60.06141 & None & 0.0000 \\
\hline 56.00809 & 40.17493 & At most 1 * & 0.0006 \\
\hline 32.68936 & 24.27596 & At most 2 * & 0.0035 \\
\hline 10.51296 & 12.32090 & At most 3 & 0.0986 \\
\hline 0.779183 & 4.129906 & At most 4 & 0.4344 \\
\hline
\end{tabular}

Table 3: Unrestricted Cointegration Rank Test (Trace)

Source: Authors' Computation, 2018

\begin{tabular}{|c|c|c|c|}
\hline Max-Eigen statistic & 0.05 Critical Value & Hypothesized No of CE(S) & Prob $^{* *}$ \\
\hline 90.48303 & 30.43961 & None & 0.0000 \\
\hline 23.31873 & 24.15921 & At most 1 & 0.0647 \\
\hline 22.17640 & 17.79730 & At most $2 *$ & 0.0103 \\
\hline 9.733777 & 11.22480 & At most 3 & 0.0904 \\
\hline 0.779183 & 4.129906 & At most 4 & 0.4344 \\
\hline
\end{tabular}

Table 4: Unrestricted Cointegration Rank Test (Max-Eigen)

Source: Authors' Computation, 2018

Table 3 and 4 revealed the results of the co integration test using Johansen Co-integration test and the rank test revealed that there is there (3) co-integrating vector among the macroeconomic variables which are significant at $5 \%$ level of significance while the Max-Eigen the indicated two (2) co-integration. It was thus concluded that there is a long run relationship among the variables 


\begin{tabular}{|c|c|c|c|c|}
\hline Variable & Coefficient & Std. Error & t-Statistic & Prob. \\
\hline D(BOT(-1) $)$ & 0.635246 & 0.312501 & 2.072782 & 0.0961 \\
\hline D(EXCH) & -16.59295 & 13.40313 & -1.237990 & 0.2301 \\
\hline D(EXP01) & 0.588328 & 0.129325 & 4.549211 & 0.0002 \\
\hline D(INTR) & 11.37031 & 44.96014 & 0.252898 & 0.8029 \\
\hline D(IMP) & -0.529378 & 0.211665 & -2.501019 & 0.0212 \\
\hline C & 205.4092 & 219.3231 & 0.936560 & 0.3602 \\
\hline ECM(-1) & -0.645763 & 0.373997 & -2.389745 & 0.0008 \\
\hline R-squared & 0.760895 & & & \\
\hline Adjusted R-squared & 0.629163 & & & \\
\hline F-statistic & 4.257864 & & & \\
\hline Prob(F-statistic) & 0.006372 & & & \\
\hline Durbin-Watson stat & 2.362951 & & & \\
\hline
\end{tabular}

Table 5: Error Correction Model

Researchers' Computation, 2018

Table 5 presents the result of the Error Correction Model. It was revealed that the first period lag of Balance of Balance has significant direct effect on Balance of Trade. The result of the Error Correction Model revealed that that Exchange Rate has negative effect on Balance of Balance with coefficient value of -16.59295 which is insignificant at 5\% level implying that an increase in exchange rate will lead to fall in Balance of Trade in Nigeria.

Furthermore, it was revealed that Export had a coefficient of 0.588328which implies that that Export has positive and significant effect on Balance of Trade and an increase in export will bring about increase in balance of Trade in Nigeria. In the same vein, Interest Rate exacted positive but insignificant effect on Balance of Trade with a coefficient value of 11.37031 indicating that an increase in Interest Rate will result in will lead to increase in Balance of Trade.

The regression result indicated that Import had negative and significant effect on Balance of Trade with a coefficient of -0.529378 indicating that an increase in Import will result in fall in Balance of Trade in the economy. Finally, it was revealed that the value of Error Correction Term (ECT) is -0.645763 with a corresponding probability value of 0.0008 which implies that that the model has a self adjustment mechanism in the short run. The implication of this is that, any disequilibrium in Balance of Trade from equilibrium state will be corrected at $65 \%$

The value of the adjusted R-Squared for the model was pegged at 0.629163 or $63 \%$, which implies that Exchange Rate, Export, Import and Interest Rate explained about 63\% systematic variation in Balance of Trade over the observed years while the remaining 37\% variation are explained by other variables not captured in the regression model. The Durbin Watson of 2.362951 shows the absence autocorrelation in the model residuals since it is in the acceptable region (i.e.1.5 $>\mathrm{d}<2.5$ ).

The overall significance is test using F-statistic which measured the joint effect of the explanatory variables on the explained variables. The F-statistic for the regression model is 4.257864 with the corresponding probability value of 0.009486 which is significant at 5\%. This implies that the explanatory variables proxied as Exchange Rate, Export, Import and Interest Rate have significant effect on Balance of Payment in Nigeria.

\begin{tabular}{|c|c|c|}
\hline Diagnostics Test & Observed Value & P-Value (Chi-Square) \\
\hline Normality Test (Jacque Bera Test) & 1.0304 & 0.5974 \\
\hline Breusch-Godfrey LM test for autocorrelation & 7.926076 & 0.3190 \\
\hline Heteroskedasticity Test: Breusch-Pagan-Godfrey & 10.05390 & 0.1224 \\
\hline Ramsey Reset Test & 0.329840 & 0.5725 \\
\hline
\end{tabular}

Table 6: Post Test Techniques

Researchers' Computation, 2018

Table 6 presents the results of residuals diagnostics test for the model. The result of the Jacque Bera normality test revealed that the residual of the regression model is normally distributed given a probability value of 0.5974 which is greater than 5\% conventional level. Also, the Breusch-Godfrey Lagranger Multiplier test (LM) revealed that the regression model is not serially correlated since the p-value of 0.3190 is greater than $5 \%$ conventional level which leads to the acceptance of null hypothesis of no serially correlation. The result of Breusch-Pegan test was conducted to check the presence heteroscedasticity in the model and it was revealed that there no heteroscedasticity in the regression model given a probability value of 0.1224 which is greater than 0.05 and implying that the model is homoscedastic. Finally it was revealed that there is no miss-specification in the model since the probability value of the Ramsey Reset Test which is given as 0.5725 is greater than $5 \%$.

\section{Conclusion, Implications and Recommendations}

Exchange rate measures the price of a country's country in relation to currencies of other nations. Exchange rate determines the trade position and competiveness level of a country in the world market. Thus, adequate management of 
exchange rate has been one of the macroeconomic thrust of developing nations including Nigeria. This study examined the effect of exchange rate on balance of trade in Nigeria.

Based on the study findings, it was established that exchange rate had insignificant effect on the balance of trade position in Nigeria which is an indication of the ineffectiveness of the country's exchange rate regime. Also, it was found that export had positive effect on balance of payment while import exacted negative effect on balance of trade which point to the over reliance of the country on imported goods and services. Despite the positive and significant effect of export on balance of trade, the export growth was not enough to offset the import that is experienced by the country. Based on findings of the study it was concluded that, exchange rate regime in Nigeria has insignificant effect on Nigeria trade balance which has continued to effect the country's international trade position negatively.

It was however recommended that monetary authorities should design effective exchange rate policies so to ensure exchange rate stability which has the capacity to improve the trade position of the country. Excessive dependent of the country on international goods and services should be curtailed through the imposition of quota on foreign goods and services and increase in tariff on foreign made goods.

Government should ensure macroeconomic variables stability. Variables like interest rate, inflation rate and others should be closely monitored and controlled so as to provide stable environment that is capable of enhancing local investments. Finally, strategic sectors such as agriculture and mining sector should be adequately financed by the government so as to increase the sources of local raw materials for domestic production thereby reducing over dependence on foreign raw materials. This will lead to increase in domestic productivities and consequently increase in export of the nation.

\section{References}

i. Adeleye, J.O., Adeteye, O.S. \& Adewunmi, M.O. (2015). Impact of international trade on economic growth in Nigeria (1988-2012). International Journal of Financial Research, 6(3), 163-172.

ii. Cote, A. (1994). Exchange rate volatility and trade - A survey. Bank of Canada, Working Paper, 94-95.

iii. Fatai, M.O. \& Akinbobola, T.O. (2015). Exchange rate pass-through to import prices, inflation and monetary policy in Nigeria. International Finance and Banking, 2(1), 60-78.

iv. Galebotswe, O. \& Andrias, T. (2011). Are devaluations contractionary in small import-dependent economies? Evidence from Botswana

v. Genc, E.G. \& Artar, O.K. (2014). The effect of exchange rates on exports and imports of emerging countries. European Scientific Journal, 10(13), 128-141

vi. Imoughele, L.E. \& Ismaila, M. (2015). The impact of exchange rate on Nigeria non-oil exports. International Journal of Academic Research in Accounting, Finance and Management Sciences, 5(1), 190-198.

vii. Ismaila, M. (2016). Exchange rate depreciation and Nigeria economic performance after structural adjustment programmes (SAPs). NG-Journal of Social Development, 59(2), 122-132.

viii. Kadil, M. (2004). Exchange rate fluctuations and economic activity in developing countries: Theory and evidence. Journal of Economic Development, 29(1), 85-108

ix. Kang, J.W. (2016). International trade and exchange rate. ADB Economics Working Paper Series, 498.

x. Khan, Z., Ali, A. \& Ali, S. (2016). Impact of devaluation on balance of trade: A case study of Pakistan economy. Asian Journal of Economic Modelling, 4(2), 90-94.

xi. Odili, O. (2014). Exchange rate and balance of payment: An autoregressive distributed lag (ARDL) econometric investigation on Nigeria. IOSR Journal of Economics and Finance, 4(6), 21-30.

xii. Odili, O. (2015). Real exchange rate volatility, economic growth and international trade in an emerging market economy: Evidence from Nigeria. International Journal of Academic Research in Business and Social Sciences, 5(7), 171-201.

xiii. Ogbonna, B.C. (2011). The impact of exchange rate variations on trade balance: Evidence from Nigeria (19702005).JORIND, 9(2). 393-403

xiv. Omofowam, S. (2014). Exchange rate risk and impact on trade. M.Sc. Thesis, University of East London.

xv. Shehu, A.A. (2013). Impact of foreign exchange volatility on imports: A case of Nigerian foreign exchange market (1987-2008). Proceedings of the 7th International Conference on Innovation \& Management

xvi. Umoru, D. \& Oseme, A.S. (2013).Trade flows and exchange rate shocks in Nigeria: An empirical result. Asian Economic and Financial Review, 3(7), 948-977 